\title{
KIT receptor-positive cells in the bovine corpus luteum are primarily theca-derived small luteal cells
}

\author{
Katharina Spanel-Borowski, Kristina Sass, Sabine Löffler, Elke Brylla, Michiharu Sakurai ${ }^{1}$ and \\ Albert M Ricken \\ Institute of Anatomy, University of Leipzig, Liebigstrasse 13, D-04103 Leipzig, Germany and ${ }^{1}$ National Institute of \\ Agrobiological Sciences, Tsukuba, Ibaraki 305-8602, Japan
}

Correspondence should be addressed to K Spanel-Borowski; Email: spanelb@medizin.uni-leipzig.de

\begin{abstract}
The tyrosine kinase KIT receptor, the protooncogene CD117, plays a key role in growth and maturation of oocytes and follicles. Relevant data are sparse for the corpus luteum (CL). We first confirmed the presence of KIT mRNA and KIT protein in bovine CL homogenates. We then localized KIT-positive (KIT+) cells in CL sections by immunohistochemistry. At the CL stage of early development, the former theca transforming into capsule/septa showed a strong band-like KIT + immunoresponse. In addition, CD45 + leukocytes in septa included subpopulations of CD45 + /KIT + and CD14 + /KIT + leukocytes as validated by double immunofluorescence localization. At the early secretory stage, KIT + cells appeared within the septa/capsule region and in the periphery of the CL parenchyma, there forming a complex network. This was separate from the capillary bed as determined by double staining for CD117 and FVIII-related endothelial cell antigen (FVIIIr). The KIT + network coincided with cells positive for cytochrome P450 $17 \alpha$-hydroxylase, a thecal cell-specific enzyme. The late secretory stage was defined by an advanced manifestation of the KIT + network in the CL periphery. At the stage of regression, the KIT + network was absent. The CL of pregnancy expressed high levels of KIT mRNA and KIT protein uniformly throughout pregnancy. The KIT + immunolocalization revealed small fibroblast-like cells, luteal cells with granules, and clusters of large luteal cells with staining of the cell membrane. We conclude that a majority of KIT + cells in the bovine CL are primarily theca-derived small luteal cells, and that a minority represent KIT + leukocytes, in some cases KIT + monocytes.
\end{abstract}

Reproduction (2007) 134 625-634

\section{Introduction}

The KIT receptor, i.e., the proto-oncogene CD117, belongs to the family of tyrosine kinase growth receptors (Taylor \& Metcalfe 2000, Rönnstrand 2004). The extracellular region of the transmembrane KIT receptor contains the binding site of the KIT ligand (stem cell factor, mast cell growth factor) and the domain for KIT dimerization after ligand binding. Various signaling pathways are triggered, e.g., phosphatidylinositol 3'kinases, Janus family kinases, Ras/Map kinases, giving rise to multiple cross connections between the pathways downstream of the KIT receptor. Because a coherent response at the gene level results from differently converging signals, the KIT ligand complex controls diverse processes. These mainly comprise cell migration, proliferation, and differentiation as well as suppression of apoptosis during hematopoiesis, melanogenesis, and gametogenesis. These processes are fundamentally disturbed in knockout mice deficient of the KIT gene and mildly affected in mutations of the intracellular receptor kinase domain, or of the Mfg gene, which encodes the KIT ligand (Besmer et al. 1993, Driancourt et al. 2000).

The fetal ovary is extremely sensitive to the KIT ligand complex. In gene-deficient mice, migration of germ cells into the genital ridge, oogenesis, and initiation of folliculogenesis fail or are impeded (Driancourt et al. 2000, Reynaud et al. 2001). The postnatal ovary appears to require the KIT ligand complex at particular steps of follicle growth and maturation. Blocking experiments in premature and mature mice with the anti-KIT antibody ACK2 indicate that the development of primordial follicles into preantral follicles is dependent on the KIT ligand complex (Yoshida et al. 1997). Preantral follicles continue to grow under KIT blockade, whereas antral follicles do not develop by lack of follicular fluid formation. Because superovulated mice develop $\mathrm{CL}$ despite the presence of blocking KIT antibody, it is said that the CL might be KIT independent. However, the KIT mRNA has been found in the ovine and porcine $\mathrm{CL}$ (Gentry et al. 1998, Brankin et al. 2004), which points to a possible KIT-dependent function. Hence, studies of the localization of the KIT protein in the $\mathrm{CL}$ are necessary. 
Because the $C L$ encompasses diverse cell types, i.e., steroidogenic and vascular cells, fibroblasts, and leukocytes, it is of special interest to identify KIT expression to particular cell types. Small luteal cells are likely candidates, because they are known to be derived from the theca where KIT transcription takes place (Driancourt et al. 2000). In addition, isolated thecal cells secrete an increased amount of progesterone under KIT stimulation when compared with unstimulated controls (Parrott \& Skinner 2000).

An important process of developing mammalian $\mathrm{CL}$ is the ingrowth of capillary sprouts from the vascular thecal layer into the avascular granulosa layer (Smith et al. 1994, Schams \& Berisha 2004). Growing vessels are considered a vehicle for the dispersion of steroidogenic cells throughout the CL (Murphy et al. 2001). According to the classical concept, granulosa cells develop into large luteal cells, while thecal cells become small luteal cells (O'Shea 1987). During CL formation, the proliferation of both luteal cell types is low. Obviously, the amount of luteinizing granulosa and thecal cells is adequate to perform an endocrine function during the estrous cycle. In the case of pregnancy, the question of luteal cell renewal is unclear. Potentially, new luteal cells differentiate from CL precursor cells into luteal cells under the appropriate stimulus. Such a precursor concept was postulated years ago (Niswender et al. 1985, 2000), but the precursor cells have not yet been found. Because bone marrow precursor/progenitor cells are characterized by KIT expression (Li et al. 2003, Fazel et al. 2006), we undertook to determine the presence or absence of KIT + cells in the bovine $\mathrm{CL}$ and whether changes in pattern are detectable during the estrous cycle and during pregnancy.

\section{Results}

\section{KIT mRNA and protein in homogenates of the cyclic bovine $C L$}

The presence of KIT mRNA in bovine $C L$ was demonstrated by RT-PCR analysis. The amplification product was a single band of the expected $465 \mathrm{bp}$ lengths, verified for all CL stages (Fig. 1A). Western blots of CL homogenates showed a band at $148 \mathrm{kDa}$, which was the characteristic size of the KIT protein. The KITsignal seemed to be high in the CL of late secretory stage and low in the developing and regressing CL (Fig. 1B).

\section{$K I T+$ cells in the cyclic CL by single and double immunolocalization}

At the early developmental stage, infoldings of the former follicular wall were still apparent giving rise to parenchymal 'lobules' of luteinizing granulosa and thecal cells. Parts of the infolded thecal cell layer shaped the capsule and the others were incorporated
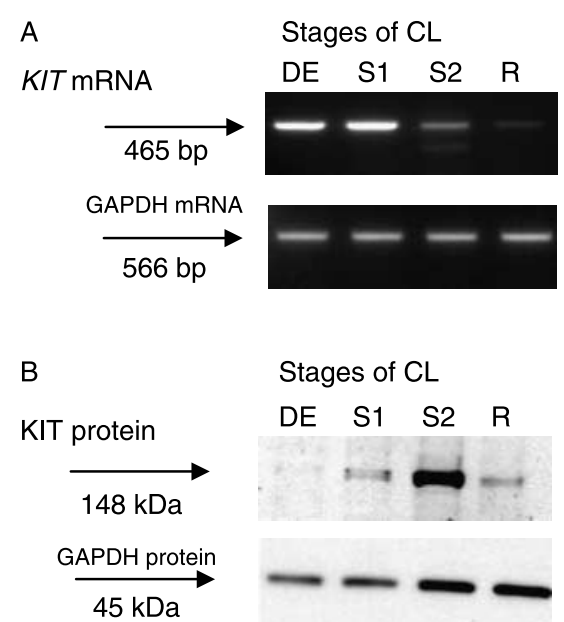

Figure $1 K I T$ mRNA and KIT protein expression in the bovine corpus luteum of different estrous cycle stages. The mRNA and protein data are representative of three independent assays. (A) The RT-PCR data show KITamplicons of $465 \mathrm{bp}$, which are lower at the late secretory stage (S2) and at $C L$ regression ( $R$, band difficult to see), when compared with the development (DE) and the early secretory stage (S1). The same cDNA gives rise to 566 bp GAPDH amplicons of comparable intensity at all stages. (B) The Western blot analysis displays an intense $148 \mathrm{kDa}$ band at the late secretory stage (S2); it is moderate at the early secretory stage $(\mathrm{S} 1)$, the regression stage $(\mathrm{R})$, and low at the developmental stage.

Reprobing with an anti-GAPDH antibody approximately documents equal protein loading.

between the 'lobules' and turned into connective tissue septa. Immunoreactivity of KIT in the former thecal cell layer appeared as a dense $\mathrm{KIT}+$ band at the very periphery of the CL (Fig. 2A). In addition, the outer thecal layer not included in the remodeling process displayed islands of $\mathrm{KIT}+$ cells, most probably leukocytes (compare Figs 2B and $5 \mathrm{~B}$ ). The KIT + islands were often found in the vicinity of venules. Both thecaderived venules and arterioles repeatedly showed a $\mathrm{KIT}+$ endothelium (Fig. 2B and C). The specificity of immunostaining was demonstrated by a preabsorption control, which abolished the reaction (negative control), and by KIT + oocytes in primary follicles as positive control (Fig. 2D, inset).

At the early secretory stage, the KIT + cell band of thecal origin was not detectable. It had segregated into $\mathrm{KIT}+$ cells of fibroblast-like shape to be seen in the septum and its boundary to the parenchyma, and additionally into a prominent KIT + network at the periphery of the $\mathrm{CL}$ parenchyma (Fig. 3A-D). There the $\mathrm{KIT}+$ cells looked like small luteal cells, which often completely surrounded the pale, large luteal cells. Occasionally, KIT + leukocytes were observed amid the luteal cells. At the late secretory stage, this KIT+ network conspicuously expanded towards the interior, yet stayed delimited from the inner CL. KIT + cells were completely absent from the central region of the $\mathrm{CL}$. The $\mathrm{KIT}+$ fibroblast-like cells abundant in the septa of early secretory stage were replaced by a few scattered KIT + 

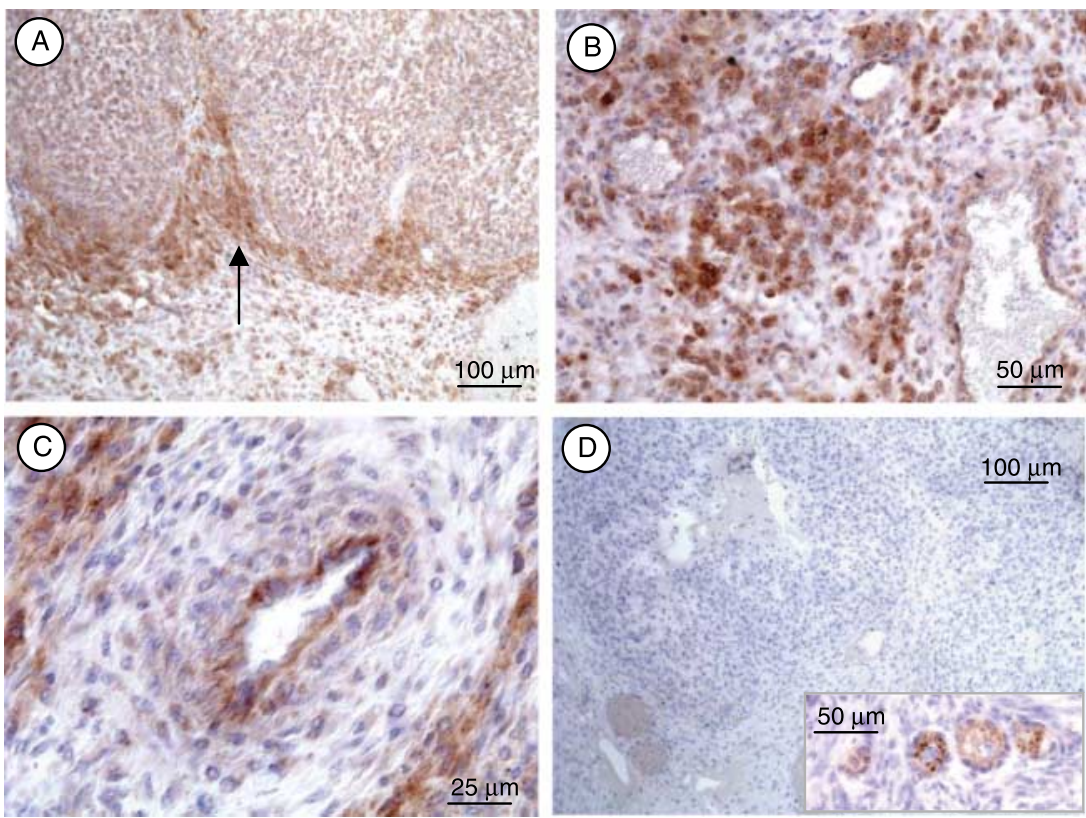

Figure 2 Immunolocalization of KIT + cells in paraffin sections of the bovine corpus luteum at the developmental stage using the polyclonal anti-KIT antibody A-4502. (A) A distinct band-like staining is observed in the very periphery of the corpus luteum (arrow) coinciding with the previous theca. (B) The outer thecal cell layer not included into the reshaping process shows KIT+ cell islands, most likely leukocytes, found close to a venule with moderate KIT + endothelial cells. (C) The medium-sized arteriole in a septum clearly shows KIT + endothelial cells. (D) KITpositive staining is abolished when the KIT antibody is pre-incubated with an excess of blocking peptide (negative control). (D inset) $\mathrm{KIT}+$ oocytes are noted in primary follicles (positive control). Scale bars as indicated. cells in the late luteal CL (Fig. 3E). These changes in distribution of KIT + cells were a reliable parameter to differentiate between the early and late secretory stages. Again, the endothelium of septal vessels exhibited KIT+ staining. All the described staining patterns disappeared by the use of preabsorbed KIT antiserum (not shown).

At the early regression stage, marked by the appearance of arterioles, the KIT + network in the periphery of
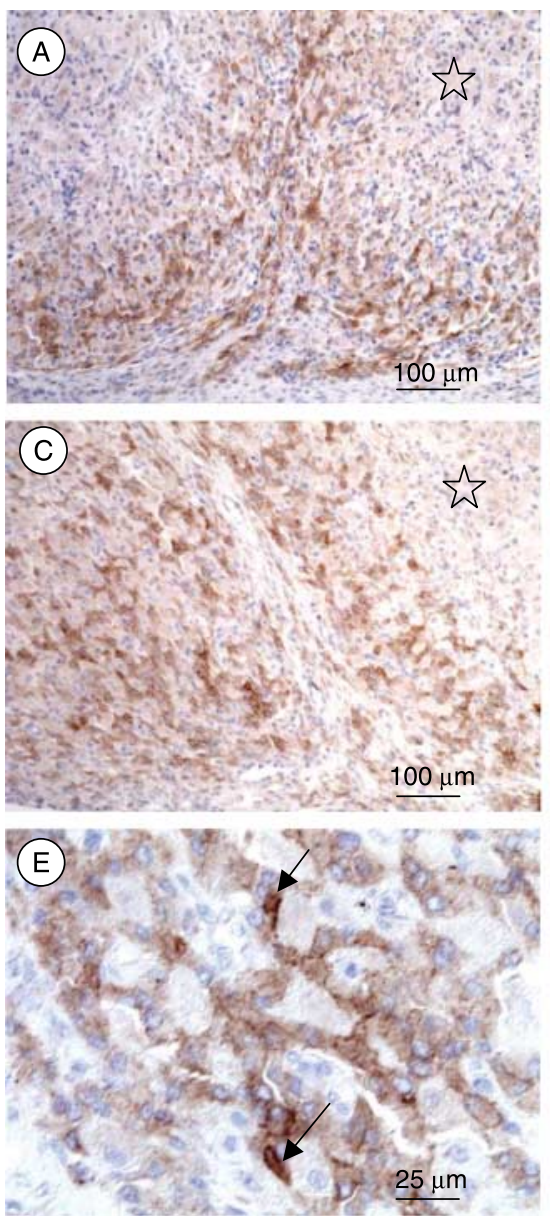
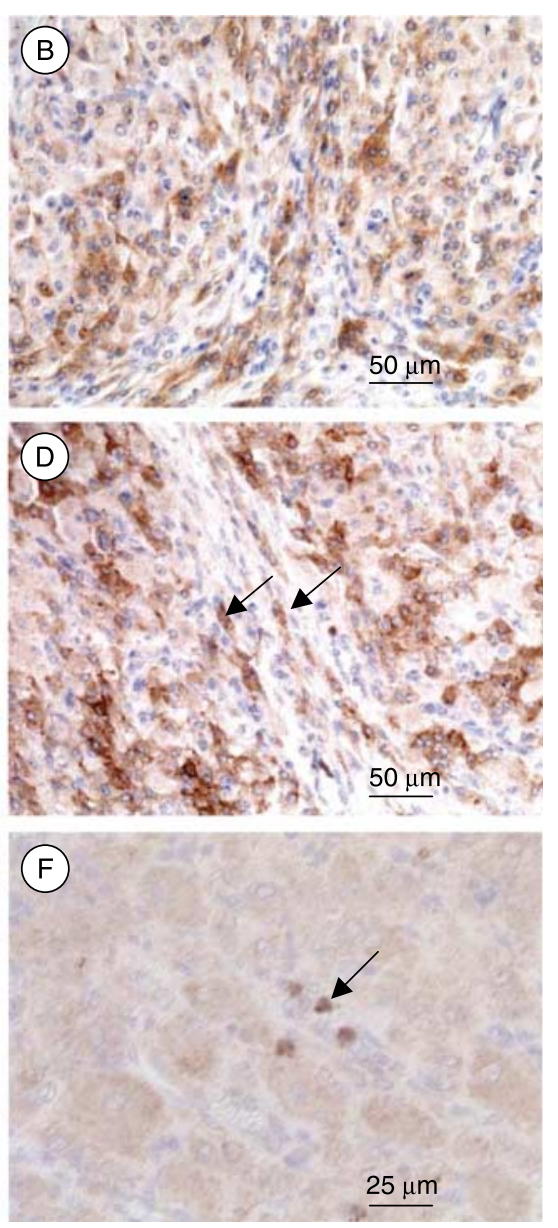

Figure 3 Immunolocalization of KIT receptorpositive cells in paraffin sections of the bovine corpus luteum at the luteal and regressing stages using the polyclonal KIT antibody A-4502.

(A) At the early secretory stage, the septum is rich in KIT + cells and a network of KIT + cells outlines the outer zone of the CL parenchyma; the inner zone lacks positive cells (star). (B) Similar to (A); KIT + cells of various sizes are apparent. (C) At the late secretory stage, the network of $\mathrm{KIT}+$ cells extends, yet stays delimited from the inner unstained zone. (D) Similar to (C); a few $\mathrm{KIT}+$ cells have remained in the septum (arrows) when compared with (B). (E) The conspicuous network consists of KIT + small luteal cells (arrows) surrounding large cells. (F) At the stage of regression, some KIT + cells have the morphology of leukocytes (arrow). The large cells display a diffuse granular-like KIT + immunoresponse, which here is barely detectable. Scale bars as indicated. 
$\mathrm{CL}$ was missing (Fig. 3F). Instead, the now dominating cell type, the large luteal cells, acquired moderate KIT + staining with pronounced cytoplasmic granules. The $\mathrm{CL}$ of regression also contained a few KIT + leukocytes, which were scattered throughout the $\mathrm{CL}$ and often gathered in the vicinity of small blood vessels. The KIT + staining including the 'granules' and the KIT+ leukocytes, disappeared by the use of preabsorption control (not shown).

At the secretory stage, large luteal cells were regularly surrounded by KIT+ small-sized cells (Fig. 3E). To identify their origin as steroidogenic thecal cells, double immunofluorescence localization was performed for KIT and CYP17. The results revealed a similar cell pattern at the early secretory stage (Fig. 4A and B). We observed some overlapping responses, which might be explained by KIT being primarily expressed at the cell membrane and CYP17 in the perinuclear zone (Fig. 4C). The specific staining for CYP17 was validated by CYP17-positive thecal cells in an antral follicle (Fig. 4D).

Double immunofluorescence localization was also performed to differentiate between KIT + cells and FVIIIr expressing endothelial cells. These results convincingly showed two interwoven, but not overlapping networks in the periphery of $\mathrm{CL}$ parenchyma (Fig. 5A). As already shown by single immunostaining (Fig. $2 \mathrm{~B}$ and $\mathrm{C}$ ), KIT + endothelial cells of arterioles, capillaries, and venules were restricted only to the capsule and the septa (not shown). We concluded that the KIT + network represented a separate identity apart from the capillary bed of the CL and that KIT + cells, being small luteal cells, were derived from steroidogenic thecal cells.

Single immunostaining with the KIT antibody marked beside luteal cells also leukocytes recruited into the $\mathrm{CL}$, as we had identified by their morphology. Double immunofluorescence for the pan leukocyte marker CD45 and KIT antigen was performed to identify a subpopulation of KIT + leukocytes in the CL. At the developmental stage, the CD45 staining detected all the leukocytes, which were preferentially localized at high density within the septal region (Fig. 5B). A subpopulation of CD45+ cells also displayed KIT + staining as revealed by the orange-yellow color of the overlapping fluorochromes (Fig. 5B and C). The $\mathrm{KIT}+/ \mathrm{CD} 45$ - luteal cells preferentially localized to the already described band-like pattern of the former theca. Some of the KIT + leukocytes were identified as monocytes by positive staining for CD14 (Fig. 5D). At the CL stage of regression, the CD45 + leukocyte population contained only a few KIT+/CD45 + leukocytes (not shown).

\section{KIT message and protein in homogenates of the bovine $C L$ of pregnancy, KIT immunolocalization}

Comparing early, middle, and late trimester of pregnancy, both KIT mRNA signal of $465 \mathrm{bp}$ and the protein band of $148 \mathrm{kDa}$ were present. The signals seemed to
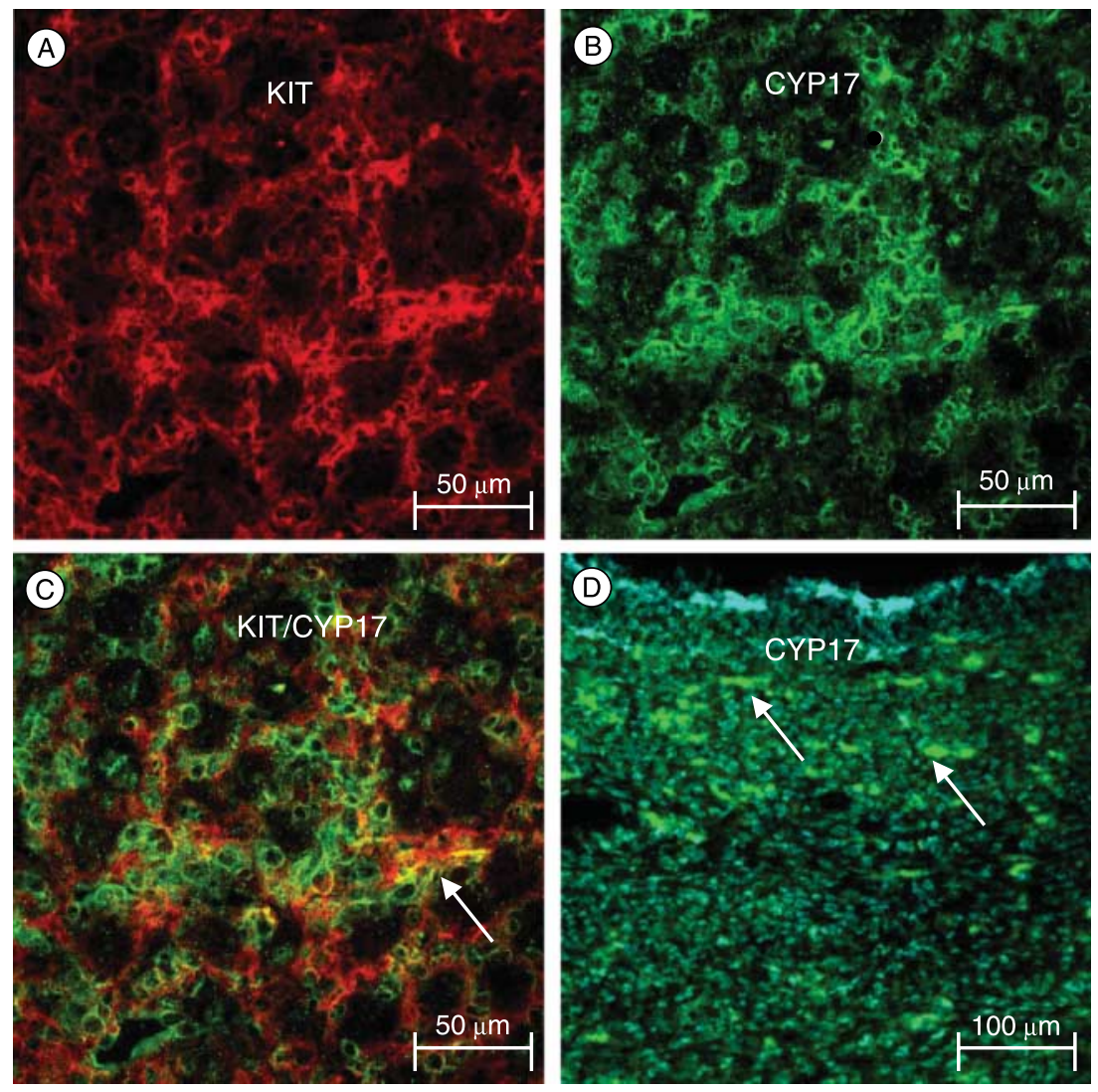

Figure 4 Double immunofluorescence localization was conducted with cryosections of the bovine corpus luteum (early secretory stage) to co-localize KIT + cells (Cy3 secondary, red) with cytochrome P450 17 $\alpha$-hydroxylase (CYP17, Cy2 secondary, green). (A and B) The KIT + network (red) is comparable in arrangement with the CYP17-positive cells (green). (C) After merging (A) and (B), some overlapping zones are clearly depicted (arrow, yellow-orange). (D) The CYP17positive thecal cells (arrows) of an antral follicle are considered as positive control. Nuclei are depicted in blue (DAPI stain). Scale bars as indicated. 

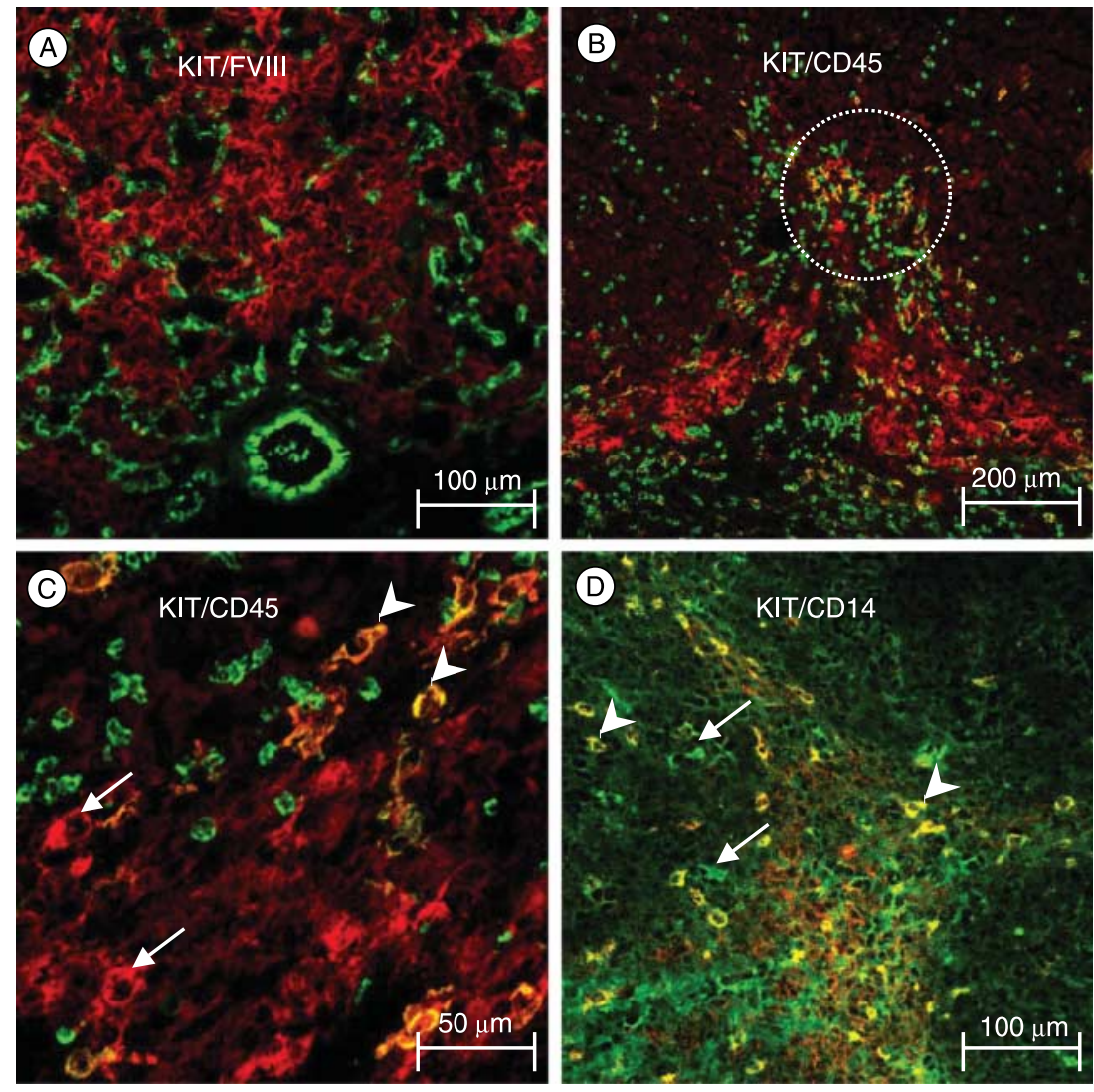

Figure 5 Double immunofluorescence localization was conducted with cryosections of the bovine corpus luteum to co-localize KIT + cells (Cy3 secondary, red) with FVIIIr-responsive endothelial cells (Cy2 secondary, green) in (A), with the pan leukocyte marker CD45 (green) in (B and C), and, finally, with the mononuclear leukocyte marker CD 14 (green) in (D). (A) At the late secretory stage, the KIT + network (red) is clearly separated from the capillary bed (A, green). (B) At the developmental stage, the infolded former theca is present as a KIT + bandlike structure (red) forming a septum, where many CD45 + leukocytes (green) are noted; some of them show an overlap with the KIT+ cells (yellow-orange, circle). (C) Similar to (B); at higher magnification, three cell categories are observed, KIT + cells (red, arrow), CD45+ leukocytes (green), and leukocytes with both signals (yellow-orange, arrow heads). (D) Two leukocyte categories are here distinctly seen in the septum of the developmental stage: CD14+ leukocytes with (yellow-orange, arrow heads) and without (green, arrows) expression of KIT. Scale bars as indicated.

persist at the same level of intensity at the time points examined before (Fig. 6).

At the morphological level, the $\mathrm{CL}$ of pregnancy displayed arterioles like the regressing $\mathrm{CL}$. Large luteal cells with KIT + granules dominated the parenchyma as we had already observed in the regressing CL. Low numbers of strongly $\mathrm{KIT}+$, fibroblast-like cells were located between large, low-responsive luteal cells and loosely gathered in proximity to vessels of former septa. Unlike in CL of the secretory stage, these KIT + cells did not form a network (Fig. 7A and B). We also found clusters of large cells depicted by a distinct KIT+ staining of the cell membrane. Neither small nor large KIT + cells displayed the additional presence of CYP17 (results not shown). The pattern of immunostaining seemed comparable for early, middle, and late trimester. Preabsorption controls always displayed blank sections.

Finally, Table 1 summarizes location and identity of $\mathrm{KIT}+$ cells in the bovine $\mathrm{CL}$ throughout the estrous cycle and pregnancy.

\section{Discussion}

The present study comprehensively describes the immunolocalization of KIT + cells in the bovine $\mathrm{CL}$ and reports on changes in the distribution pattern and cell types during the estrous cycle and pregnancy. Findings are relevant to the physiological alterations of
A

$$
\text { Crown rump length }[\mathrm{cm}]
$$

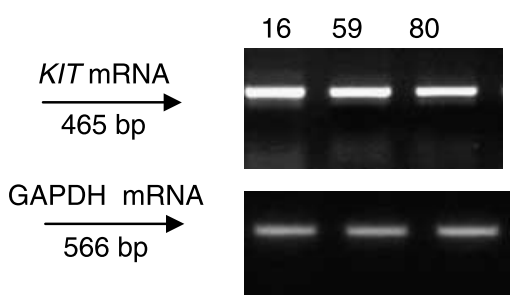

B

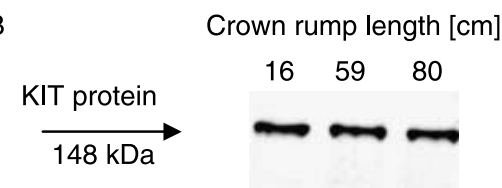

$\underset{45 \mathrm{kDa}}{\stackrel{\text { GAPDH protein }}{\longrightarrow}} \longrightarrow$

Figure $6 K I T$ mRNA and KIT protein are studied in the bovine corpus luteum of early, middle, and late trimester of pregnancy. mRNA and protein data are representative of three independent assays. (A) The RT-PCR data reveal KIT amplicons of 465 bp; they appear to be present in similar amounts throughout pregnancy. The same cDNA gives rise to 566 bp GAPDH fragments of equal density. (B) The Western blot data show comparably intense bands from early to late pregnancy. Reprobing with anti-GAPDH antibody reveals equal protein loading. 

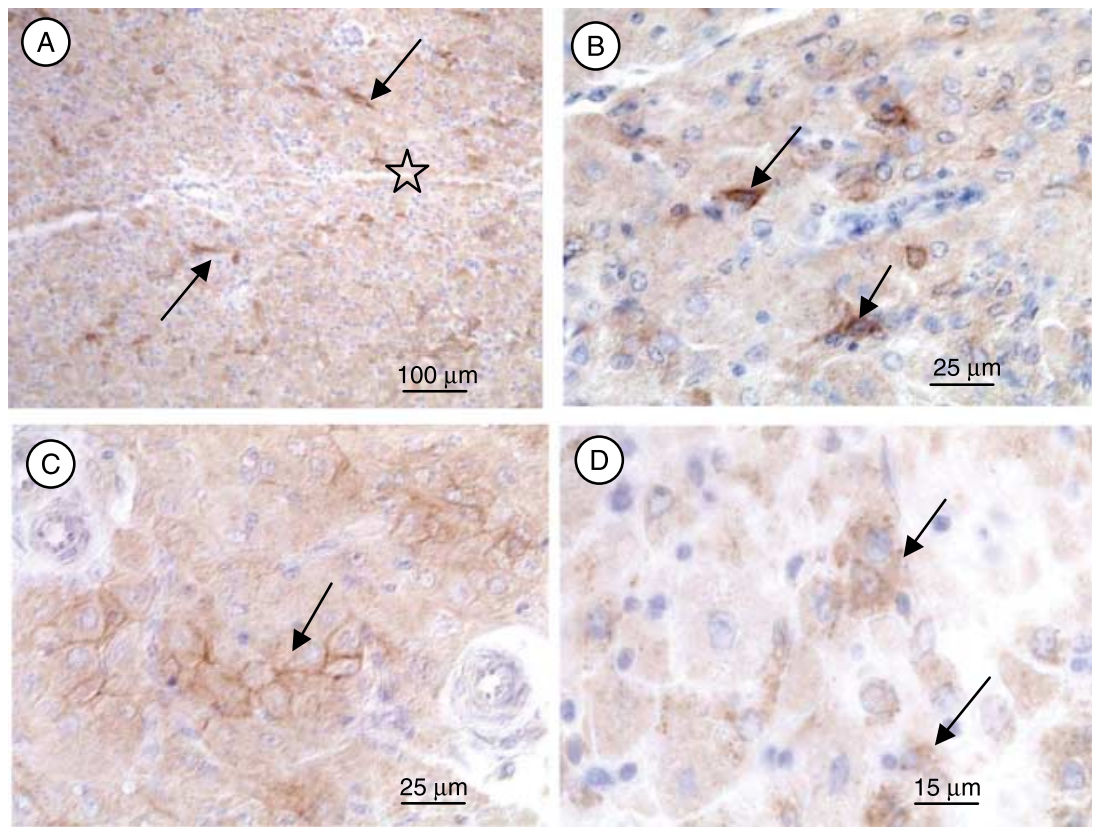

Figure 7 Immunolocalization of KIT+ cells in paraffin sections of the bovine corpus luteum of late trimester pregnancy using the polyclonal KIT antibody A-4502. (A) KIT + cells (arrows) are scattered around the small septum (star). (B) Small KIT + cells (arrows) are reminiscent of fibroblasts. (C) A cluster of large luteal cells shows $\mathrm{KIT}+$ cell membranes (arrows). (D) A subgroup of large luteal cells display granule-like KIT+ structures (arrows). Scale bars as indicated.
$\mathrm{KIT}+$ endocrine cells in the bovine $\mathrm{CL}$ and to the recruitment of KIT + leukocytes into the CL. Our results thus significantly add to the body of knowledge on KIT + cells in the CL. In the sheep, KIT+ cells were detected in the $\mathrm{CL}$ by in situ hybridization without giving reference to the CL stage (Gentry et al. 1998). In the pig, different estrous cycle stages were examined, detecting low expression of KIT mRNA at the developmental stage and high expression at the secretory stage (Brankin et al. 2004). We are therefore careful about the current finding on a strong KIT mRNA signal in the CL of developmental stage as long as the quantitative assessment of KIT mRNA is missing. Our primers for RT-PCR analysis of KIT mRNA were based on GenBank accession no. D16680 as published by Kubota et al. (1994), thereafter confirmed by two other published bovine sequences (GenBank accession nos AF263827 and XM_612028). The amplified region of the bovine KIT gene is homologous to KIT of other species, but is different from related members of the platelet-derived growth factor receptor subfamily. Moreover, we also found the KIT protein in homogenates of the cyclic CL with likely elevated expression at the secretory stage and in the CL of pregnancy.

An immunohistochemical approach was used to identify the KIT-expressing cells and patterns in the bovine CL. The technique of Hoyer et al. (2005) was used, who carried out KIT antigen retrieval by microwave treatment at $\mathrm{pH}$ 9.0. It became evident that KIT + cells exist in changing CL compartments. At the developmental stage, we found a strong KIT + band-like pattern of expression in the former thecal layer. According to other groups, thecal cells of antral follicles express both KIT+ mRNA and KIT protein (Motro \& Bernstein 1993, Parrott \& Skinner 1997, Driancourt et al. 2000, Brankin et al. 2004). Obviously, the KIT expression persists after ovulation in the theca-derived capsule/septum in

Table 1 Summary of location and identity for KIT + cells in the bovine corpus luteum belonging to the four major cell types, i.e., luteal cells, vascular cells, fibroblasts.

\begin{tabular}{|c|c|c|c|}
\hline \multirow[b]{2}{*}{ CL stage } & \multirow[b]{2}{*}{ Capsule/septum } & \multicolumn{2}{|l|}{ Parenchyma } \\
\hline & & Peripheral zone & Inner zone \\
\hline Development & $\begin{array}{l}\text { Band-like cell pattern, groups of poly- and } \\
\text { mononuclear leukocytes, endothelial cells }\end{array}$ & Scattered poly- and mononuclear leukocytes & None \\
\hline \multicolumn{4}{|l|}{ Secretory stage } \\
\hline Early & Fibroblast-like cells, endothelial cells & $\begin{array}{l}\text { Developing network of small luteal cells, a few } \\
\text { leukocytes }\end{array}$ & None \\
\hline Late & A few fibroblast-like cells, endothelial cells & $\begin{array}{l}\text { Stabilized and delimited network of small } \\
\text { luteal cells, a few leukocytes }\end{array}$ & None \\
\hline Regression & & Luteal cells with granules, leukocytes & As in the peripheral zone \\
\hline Pregnancy & & $\begin{array}{l}\text { Large luteal cells with granules, cell clusters } \\
\text { with positive cell membranes, fibroblast-like } \\
\text { cells }\end{array}$ & $\begin{array}{l}\text { All over large luteal cells with } \\
\text { granules }\end{array}$ \\
\hline
\end{tabular}


fibroblast-like cells and in small luteal cells. In situ hybridization studies in the ovine $\mathrm{CL}$ also detected KIT mRNA in small luteal cells (Gentry et al. 1998). During the secretory stage of the bovine CL, KIT + fibroblast-like cells reside in the septum close to blood vessels and might also be recruited into the parenchyma, probably under KIT ligand stimulation. Recruitment of KIT+ stromal cells to primary follicles after KIT ligand stimulation has been found in the cortex of the adult bovine ovary (Parrott \& Skinner 2000).

Apart from vascular cells, the thecal layer consists of steroidogenic cells and fibroblasts, both of which are candidate cells for the small KIT + cells in the bovine CL. We here clearly show by double-immunostaining of KIT and the thecal cell-specific enzyme CYP17 that the $\mathrm{KIT}+$ network in the peripheral zone of the CL was derived from the steroidogenic thecal cells. The presence of CYP17-positive cells in the CL's periphery seems to be a ruminant-specific feature (Conley et al. 1995).

In the bovine $\mathrm{CL}$ of secretory stage, the small-sized $\mathrm{KIT}+$ cells form a peripheral network surrounding the large luteal cells. Using double-immunostaining of the $\mathrm{CL}$, we verified that the FVIIIr-positive microvascular bed is separate from the KIT + network. Since neovascularization of the CL has its origin in the invading theca, the intimate vicinity of both networks would allow for a molecular crosstalk between small KIT + luteal cells and sprouting endothelial cells. It is conceivable that this cellular arrangement is engaged in the replenishment of capillaries in the CL. Recent studies of induced angiogenesis identified perivascular fibroblasts and smooth muscle cells with stromal-derived factor 1 expression being responsible for the retention of recruited proangiogenic cells in peripheral tissues (Ruiz de Almodovar et al. 2006). Among other retention candidates, KIT and KIT ligand are also discussed (Quesenberry et al. 2005, Grunewald et al. 2006). In the inner CL zone, which is free of KIT+ cells, different factors might be necessary to stabilize the microvascular bed. For example, angiopoetin-1 and its specific receptor Tie-2, which control blood vessel stabilization and are abundant in the mid-luteal phase of the human $\mathrm{CL}$, might be involved (Sugino et al. 2005).

The complete disappearance of the KIT + network at the stage of regression, characterized by degradation of the capillaries, also indicates a KIT function in neovascularization of CL. Examination of the localization of the KIT + network suggests that early in luteolysis, the KIT + cells undergo programmed cell death, or luteolytic factors, e.g., prostaglandin F2 $\alpha$, vasoactive peptides, etc. (Schams \& Berisha 2004), influence KIT expression and processing.

In the CL of pregnancy, large luteal cells are dominant, which is indicative of a high steroidogenic output. Some of them display a KIT+ cell membrane, possibly indicating de novo induction of KIT. Alternatively, the $\mathrm{KIT}+$ large cells have originated from small KIT + cells, which reside close to the small septum. We could not confirm this transformation by the presence of CPY17 positivity in KIT + cells (unpublished) and therefore deduce that the thecal cell-specific marker is missing in the $\mathrm{CL}$ of pregnancy. This is in line with the literature describing lack of CYP17 expression in the bovine CL (Rodgers et al. 1986, Conley et al. 1995). Our observation revisits the discussion of whether small thecal cells remain small cells or alternately transform into large luteal cells (Niswender et al. 1985, 2000). The small KIT + cells with a rather diffuse immunostaining might represent theca-derived cells and contribute to cell renewal in pregnancy.

At present, a new concept is emerging that KIT + cells from the bone marrow contribute to the self-healing potential of the body. These bone marrow-derived KIT+ cells migrate for angiogenic repair into a remote organ such as ischemic hindlimb, myocardium after infarction, and injured femoral artery, there secreting angiogenic cytokines (Li et al. 2003, Fazel et al. 2006, Wang et al. 2006). This regenerative mechanism may have a physiological counterpart in the vascularization of the CL. We have described that macrophage-like cells from bovine antral follicles proliferate in co-culture with granulosa cells (Spanel-Borowski \& Ricken 1997). Others have isolated immature, hematopoietic cells from the ovarian murine stroma expressing high KIT levels. In culture, these cells retained long-term proliferative capacity and eventually differentiated into CD45 + monocytes/macrophages (Pascual et al. 2005). In the developing bovine $\mathrm{CL}$, we have also reported on the correlation of microvessel sprouting and the recruitment of CD18-positive leukocytes into the capsule/septa area (Spanel-Borowski et al. 1997). Of note, $90 \%$ of all leukocytes have been defined as eosinophils, which do not colonize together with mast cells (Reibiger \& Spanel-Borowski 2000). It can thus be deduced that $<10 \%$ of the $C L$ invading leukocytes are $\mathrm{CD} 14+$ monocytes containing a KIT + subpopulation. It is assumed that these particular monocytes might be derived from the bone marrow, which contains KIT+ hematopoietic progenitor cells in the bovine system (Hikono et al. 2001). The KIT + leukocytes might provide a local pool of progenitor cells, which could ensure recruitment of cells for angiogenesis, steroidogenesis, or production of CL-specific signals like growth factors, chemokines, etc.

Our findings convincingly demonstrate KIT + small luteal cells, which have originated from the former thecal layer and which persist in the $\mathrm{CL}$ periphery. In addition, a subpopulation of KIT + monocytes are detectable in the septum/capsule area of the bovine $\mathrm{CL}$ of early development. Further studies are needed to corroborate whether, similar to the promotion of follicular development by the KIT-KIT ligand complex (Carlsson et al. 2006, Hutt et al. 2006), the CL life cycle also depends on KIT and KIT ligand-expressing cells. 


\section{Materials and Methods}

\section{Ovaries}

Ovaries with $\mathrm{CL}$ were removed from non-pregnant and pregnant cows immediately after death at the local abattoir. Cyclic CL stages were classified at the macroscopical level according to Ireland et al. (1980). Development, early and late secretory stage, and early regression were finally confirmed by immunostaining for factor VIII-related antigen (FVIIIr) to reveal differences in the microvascular bed (Ricken et al. 1995). For collection of CL during pregnancy, uterine horns were opened and the fetus removed for measurement of the crown-rump length (Sakumoto et al. 2000): trimester I, fetal crown-rump length $6-20 \mathrm{~cm}$; trimester II, 25-45 cm; and trimester III, $50-80 \mathrm{~cm}$. The samples were transported in PBS ( $\mathrm{pH} 7.4)$ to the laboratory. Each $\mathrm{CL}$ was dissected free from cortical tissue; samples were either snap frozen in liquid nitrogen and stored at $-80{ }^{\circ} \mathrm{C}$ until use for PCR analysis, Western blotting, and cryostat sections or otherwise fixed with Serra (12 parts $95 \%$ ethanol, 6 parts $35 \%$ paraformaldehyde, and 1 part glacial acetic acid) for embedding in paraffin wax. For each technique, unrelated CL were used, at least $n=3$ per estrous cycle stage and pregnancy stage.

\section{RNA isolation, CDNA synthesis, and RT-PCR analysis}

Frozen CL were crushed into powder with a pestle and mortar in liquid nitrogen, and total RNA was isolated using the peqGOLD RNAPURE isolation kit (PEQLAB GmbH, Erlangen, Germany). Genomic DNA was digested with 0.02 U DNase/ $\mu \mathrm{g}$ RNA (Roche Molecular Biochemicals). RNA of $5 \mu \mathrm{g}$ was taken to synthesize cDNA using a first-strand cDNA synthesis kit from Amersham Pharmacia Biotech by use of oligo-dT primers in a $15 \mu \mathrm{l}$ reaction volume. RT-PCR technique was used to amplify a KIT mRNA fragment from bovine CL cDNA (Table 2). KIT primers were designed using the GenBank deposited Bos taurus sequences (no. D16680). Primers did not match to the sequences of the platelet-derived growth factor receptor subfamily. Each $25 \mu \mathrm{l}$ amplification reaction contained $2.5 \mu \mathrm{l}$ $10 \times$ concentrated PCR buffer $\left(15 \mathrm{mM} \mathrm{MgCl}_{2}\right), 0.3 \cup$ Taq DNA polymerase (Roche Molecular Biochemicals), $100 \mu \mathrm{M}$ dNTPs (Perkin-Elmer, Weiterstadt, Germany), $0.1 \mu \mathrm{M}$ of each primer, and $1 \mu \mathrm{l}$ sample cDNA. According to our standard laboratory protocol, the product was amplified by 40 cycles as $465 \mathrm{bp}$ amplicons. Amplified fragments were cloned into pGEM-T (Promega). Clones harboring cDNA inserts of expected sizes were isolated and sequenced. Subsequent identification of the cDNA inserts was obtained by interrogation of GenBank (BLAST search). Glyceraldehyde-3-phosphate dehydrogenase
(GAPDH), amplified as 566 bp fragments, was used for equal loading. RT-PCR analysis was carried out without sample cDNA as negative control (not shown).

\section{Western blotting}

Crushed $\mathrm{CL}$ were homogenized in $1 \mathrm{ml}$ ice-cold homogenization buffer ( $\mathrm{pH} 7.4$ ) composed of 20 mM HEPES, $1 \mathrm{mM}$ EDTA, $0.2 \mathrm{M}$ sucrose, $0.1 \mathrm{mM}$ phenylmethylsulfonyl fluoride, and $0.5 \%$ SDS. After further homogenization by ultrasonification, samples were centrifuged twice at $16000 \times \mathbf{g}$ (13 000 r.p.m.) at $4{ }^{\circ} \mathrm{C}$ for $15 \mathrm{~min}$. Cell lysates were diluted 1:1 in sample buffer (250 mM Tris- $\mathrm{HCl}$ (pH 6.8) containing 4\% SDS, $10 \%$ glycerol, and $2 \% \quad \beta$-mercaptoethanol) and denaturated at $95{ }^{\circ} \mathrm{C}$ for 5 min. Protein content of cell lysates was determined by the bicinchoninic acid assay using bovine albumin as standard (Pierce, Rockford, IL, USA). Proteins (15 $\mu \mathrm{g} / \mathrm{lane})$ were separated by SDS- $(7.5 \%)$ PAGE and transferred to a nitrocellulose membrane by electroblotting. Upon blocking non-specific binding sites with 5\% non-fat milk for 30 min, blots were incubated with the 1:3000 diluted anti-KIT rabbit polyclonal antibody (Santa Cruz Biotechnology Inc., Santa Cruz, CA, USA) overnight. The final incubation was performed with a horseradish peroxidase-labeled donkey anti-rabbit secondary antibody (1:6000 dilution; Dianova, Hamburg, Germany) for $2 \mathrm{~h}$. Immunoreactive proteins were visualized using a chemiluminescence kit and Hyperfilm (Amersham Pharmacia Biotech). Equal protein loading was confirmed by stripping the blots and reprobing with a monoclonal antiGAPDH antibody (1:10 000; Research Diagnostics, Flanders, The Netherlands).

\section{Immunohistochemistry for KIT localization}

The technique of Hoyer et al. (2005) was performed with minor modifications using antigen retrieval and Envision method (DakoCytomation, Glostrup, Denmark). We selected the rabbit anti-human CD117 antiserum (A4502, DakoCytomation), because comparative evaluations attested this product's high specificity and sensitivity (Lucas et al. 2003, Vakiani et al. 2005). Additionally, the antiserum was successfully applied to reveal KIT + Cajal cells in the bovine gut (Marquez et al. 2006).

Paraffin sections $(7 \mu \mathrm{m})$ were mounted on poly-L-lysincoated glass slides, dewaxed, and washed $3 \times$ with TBS buffer (0.05 M Tris ( $\mathrm{pH} 7.6), 0.15 \mathrm{M} \mathrm{NaCl})$ containing $0.01 \%$ Nonidet P-40 (TBS/NP40). To unmask antigens, CL sections were pretreated with microwaves in $0.02 \mathrm{M}$ Tris $(\mathrm{pH}$ 9.0) and $0.5 \mathrm{mM}$ EDTA as follows: $800 \mathrm{~W}$ for $5 \mathrm{~min}, 100 \mathrm{~W}$ for $15 \mathrm{~min}$, and then cooled to room temperature (RT). Endogenous

Table 2 Bovine primer for mRNA detection of KIT and glyceraldehyde-3-phosphate dehydrogenase (GAPDH).

\begin{tabular}{|c|c|c|c|c|c|}
\hline Gene product & mRNA accession no. & Nucleotide-sequence $5^{\prime}-3^{\prime}$ & Orientation & ${ }^{\circ} \mathbf{C}^{\mathbf{a}}$ & $b p^{b}$ \\
\hline KIT-R & D16680 & CAAGCGCCCATTTAACCGAACGAG & Sense & 61.1 & 465 \\
\hline GAPDH & U85042 & $\begin{array}{c}\text { ACGCCATGCCTTTTGCCACCTG } \\
\text { TGAAGGGTGGCGCCAAGAGG } \\
\text { TGCCAGCCCCAGCATCGAAG }\end{array}$ & $\begin{array}{l}\text { Antisense } \\
\text { Sense } \\
\text { Antisense }\end{array}$ & 64 & 566 \\
\hline
\end{tabular}

${ }^{\mathrm{a} A n n e a l i n g ~ t e m p e r a t u r e ~ u s e d ~ i n ~ r e a c t i o n . ~}{ }^{\mathrm{b}} \mathrm{PCR}$ product length. 
peroxidase activity was quenched with $0.45 \% \quad \mathrm{H}_{2} \mathrm{O}_{2}$ in TBS/NP40 for $15 \mathrm{~min}$ at RT. Sections were washed $1 \times$ in TBS with $0.125 \%$ Tween (TBS/Tween), $2 \times$ in TBS, and incubated in $10 \%$ normal goat serum in TBS/NP40 at RT to block nonspecific binding for $30 \mathrm{~min}$. The primary antiserum was diluted (concentration $100 \mu \mathrm{g} / \mathrm{ml}$ ) in PBS with $0.25 \%$ BSA (A-4378, Sigma-Aldrich) and applied at $4{ }^{\circ} \mathrm{C}$ overnight. To control the specificity of KIT staining, the antiserum was incubated with $100 \times$ molar excess of the antigenic peptide (PP-1518, LAB VISION Corp., Fremont, CA, USA) at $4{ }^{\circ} \mathrm{C}$ overnight, the immunoprecipitates were removed by repeated centrifugation, and the supernatants applied to sections. Next day, slides were successively washed $3 \times$ in TBS/Tween and TBS alone, and then incubated with DakoCytomation Envision System (Labelled Polymer-HRP Anti-rabbit, K4002; DakoCytomation) at RT for $30 \mathrm{~min}$. Sections were washed and incubated with $0.025 \% 3^{\prime}, 3^{\prime}$-diaminobenzidine (Sigma-Aldrich) in $0.05 \mathrm{M}$ Tris $(\mathrm{pH} 7.6), 0.03 \% \mathrm{H}_{2} \mathrm{O}_{2}$ for 6 min. Sections were counterstained with hematoxylin, dehydrated, and mounted in Histokitt (Carl Roth GmbH, Karlsruhe, Germany).

\section{Double immunofluorescence localization of KIT and FVIIIr, or cytochrome P450 17 $\alpha$-hydroxylase (CYP17), or CD45, or CD14}

KIT was co-localized by use of the monoclonal anti-KIT antibody bk-1 (Hikono et al. 1999) and (a) the polyclonal antibody against the cytochrome P450 17 $\alpha$-hydroxylase (CYP17), which is a selective key enzyme of steroidogenic thecal cells; the anti-CYP17 antibody was a kind gift from Prof. M R Waterman, Vanderbilt University, Nashville, TN, USA (Rodgers et al. 1986). There are reports that CYP17 is not highly expressed or absent in the bovine CL (Rodgers et al. 1986, Conley et al. 1995). In our hands, the anti-CYP17 antibody gave a positive signal in the former thecal cells of the developing $\mathrm{CL}$ and at the early stage of secretion. This CYP17 signal decreased thereafter. The monoclonal anti-KIT antibody was also applied with b) FVIIIr using the polyclonal anti-FVIIIr antiserum (DakoCytomation). KIT was finally c) co-localized with leukocyte markers; the polyclonal anti-KIT antiserum (DakoCytomation) was combined with the monoclonal antibovine CD45 antibody (VMRD Inc., Pullman, WA, USA), which localizes all leukocytes, and also with the monoclonal anti-bovine CD 14 antibody, clone BAQ151 (VMRD Inc.), for monocytes respectively.

Cryosections $(10 \mu \mathrm{m})$ of $\mathrm{CL}$ samples were mounted on coated glass slides, postfixed in ice-cold methanol/ethanol, $1: 1$, air-dried and rehydrated in PBS buffer. Sections were incubated with the monoclonal anti-KIT antibody $(20 \mu \mathrm{g} / \mathrm{ml})$ or the polyclonal anti-KIT antiserum $(100 \mu \mathrm{g} / \mathrm{ml})$ diluted in antibody buffer (10 mg BSA/PBS) at $4{ }^{\circ} \mathrm{C}$ overnight. Thereafter, the Cy3-conjugated secondary antibody $(7.5 \mu \mathrm{g} / \mathrm{ml}$; Dianova) was applied at RT in the dark for $1 \mathrm{~h}$. The secondary antibody was chosen in such a way that it corresponded to the species, in which the primary anti-KIT antibody had been generated. In the second round staining, sections, labeled before with the monoclonal antibody bk-1, were incubated with the polyclonal anti-CYP17 (diluted 1:1000) or with the polyclonal antiFVIIIr antiserum (concentration: $3.1 \mu \mathrm{g} / \mathrm{ml}$ ), whereas sections treated with the polyclonal anti-KIT antiserum were treated with the monoclonal anti-CD45 antibody or the anti-CD14 antibody (both diluted $10 \mu \mathrm{g} / \mathrm{ml}$ ). Incubation with secondary antibodies conjugated with Cy2 $(7.5 \mu \mathrm{g} / \mathrm{ml}$; Dianova) was conducted as described above. Finally, nuclei were stained with $1 \mu \mathrm{g} / \mathrm{ml}$ 4'-6-diamidino-2-phenylindole (Serva, Heidelberg, Germany) in PBS for $1 \mathrm{~min}$. Between each incubation step, thorough rinsing with washing buffer $(0.1 \mathrm{mg} \mathrm{BSA} / \mathrm{ml}$ PBS) was performed. Air-dried sections were finally mounted in Entellan (Merck). Non-specific staining was judged by the use of nonspecific IgG instead of the primary antibody.

\section{Photodocumentation}

Pictures were taken by a light microscope (Axioplan 2, Zeiss, Jena, Germany) equipped either with a digital camera and the Image Access Software (Image, Glattburg, Switzerland) or with an epifluorescence illumination together with an axiovision camera. For double immunofluorescence localization, pictures were documented with a laser scanning microscope LSM 510 Meta (Zeiss). It allowed the reduction of nonspecific staining by minimizing crossover interference during scanning.

\section{Acknowledgements}

Prof. M R Waterman, Vanderbilt University, Nashville, TN, USA kindly supplied the anti-CYP17 antibody. We cordially thank Silke Kiessling for the successful support in the Western blotting technique, and Angela Ehrlich for her regular rides to the local abattoir as well as for her beautiful double immunofluorescence staining. The authors declare that there is no conflict of interest that would prejudice the impartiality of this scientific work.

\section{References}

Besmer P, Manova K, Duttlinger R, Huang EJ, Packer A, Gyssler C \& Bachvarova RF 1993 The kit-ligand (steel factor) and its receptor KIT/W: pleiotropic roles in gametogenesis and melanogenesis. Development Supplement 125-137.

Brankin V, Hunter MG, Horan TL, Armstrong DG \& Webb R 2004 The expression patterns of mRNA-encoding stem cell factor, internal stem cell factor and KIT in the prepubertal and adult porcine ovary. Journal of Anatomy 205 393-403.

Carlsson IB, Laitinen MP, Scott JE, Louhio H, Velentzis L, Tuuri T, Aaltonen J, Ritvos O, Winston RM \& Hovatta O 2006 Kit ligand and KIT are expressed during early human ovarian follicular development and their interaction is required for the survival of follicles in long-term culture. Reproduction 131 641-649.

Conley AJ, Kaminski MA, Dubowsky SA, Jablonka-Shariff A, Redmer DA \& Reynolds LP 1995 Immunohistochemical localization of 3 betahydroxysteroid dehydrogenase and P450 17 alpha-hydroxylase during follicular and luteal development in pigs, sheep, and cows. Biology of Reproduction 52 1081-1094.

Driancourt MA, Reynaud K, Cortvrindt R \& Smitz J 2000 Roles of KIT and KIT LIGAND in ovarian function. Reviews in Reproduction 5 143-152.

Fazel S, Cimini M, Chen L, Li S, Angoulvant D, Fedak P, Verma S, Weisel RD, Keating A \& Li RK 2006 Cardioprotective KIT + cells are from the bone marrow and regulate the myocardial balance of angiogenic cytokines. Journal of Clinical Investigation 116 1865-1877.

Gentry PC, Smith GW, Leighr DR, Bao B \& Smith MF 1998 Ontogeny of stem cell factor receptor (KIT) messenger ribonucleic acid in the ovine corpus luteum. Biology of Reproduction 59 983-990. 
Grunewald M, Avraham I, Dor Y, Bachar-Lustig E, Itin A, Jung S, Chimenti S, Landsman L, Abramovitch R \& Keshet E 2006 VEGFinduced adult neovascularization: recruitment, retention, and role of accessory cells. Cell 124 175-189.

Hikono H, Ohta M, Kubota T, Zhou JH, Inumaru S \& Sakurai M 1999 Production and characterization of monoclonal antibodies that recognize bovine Kit receptor. Veterinary Immunology and Immunopathology 68 101-112.

Hikono H, Ohta M, Zhou JH \& Sakurai M 2001 Expression and distribution of the Kit receptor in bovine bone marrow cells. American Journal of Veterinary Research 62 974-977.

Hoyer PE, Byskov AG \& Mollgard K 2005 Stem cell factor and KIT in human primordial germ cells and fetal ovaries. Molecular and Cellular Endocrinology 234 1-10.

Hutt KJ, McLaughlin EA \& Holl MK 2006 KIT/KIT ligand in mammalian oogenesis and folliculogenesis: roles in rabbit and murine ovarian follicle activation and oocyte growth. Biology of Reproduction 75 421-433.

Ireland JJ, Murphee RL \& Coulson PB 1980 Accuracy of predicting stages of bovine estrous cycle by gross appearance of the corpus luteum. Journal of Dairy Science 63 155-160.

Kubota T, Hikono H, Sasaki E \& Sakurai M 1994 Sequence of a bovine KIT proto-oncogene cDNA. Gene 141 305-306.

Li TS, Hamano K, Nishida M, Hayashi M, Ito H, Mikamo A \& Matsuzaki M $2003 \mathrm{CD} 117$ + stem cells play a key role in therapeutic angiogenesis induced by bone marrow cell implantation. American Journal of Physiology 285 H931-H937.

Lucas DR, Al-Abbadi M, Tabaczka P, Hamre MR, Weaver DW \& Mott MJ 2003 KIT expression in desmoid fibromatosis. Comparative immunohistochemical evaluation of two commercial antibodies. American Journal of Clinical Pathology 119 339-345.

Marquez SG, Galotta JM, Portiansky EL \& Barbeito CG 2006 Characterization of interstitial cells of Cajal in bowel of cattle (Bos taurus). Veterinary Research Communication 30 221-229.

Motro B \& Bernstein A 1993 Dynamic changes in ovarian KIT and Steel expression during the estrous reproductive cycle. Developmental Dynamics 197 69-79.

Murphy BD, Gevry N, Ruiz-Cortes T, Cote F, Downey BR \& Sirois J 2001 Formation and early development of the corpus luteum in pigs. Reproduction Supplement 58 47-63.

Niswender GD, Schwall RH, Fitz TA, Farin CE \& Sawyer HR 1985 Regulation of luteal function in domestic ruminants: new concepts. Recent Progress in Hormone Research 41 101-151.

Niswender GD, Juengel JL, Silva PJ, Rollyson MK \& McIntush EW 2000 Mechanisms controlling the function and life span of the corpus luteum. Physiological Reviews 80 1-29.

O'Shea JD 1987 Heterogeneous cell types in the corpus luteum of sheep, goats and cattle. Journal of Reproduction and Fertility 34 71-85.

Parrott JA \& Skinner MK 1997 Direct actions of kit-ligand on theca cell growth and differentiation during follicle development. Endocrinology 138 3819-3827.

Parrott JA \& Skinner MK 2000 Kit ligand actions on ovarian stromal cells: effects on theca cell recruitment and steroid production. Molecular Reproduction and Development 55 55-64.

Pascual CJ, Sanberg PR, Chamizo W, Haraguchi S, Lerner D, Baldwin M \& El Badri NS 2005 Ovarian monocyte progenitor cells: phenotypic and functional characterization. Stem Cells and Development 14 173-180.
Quesenberry PJ, Colvin G \& Abedi M 2005 Perspective: fundamental and clinical concepts on stem cell homing and engraftment: a journey to niches and beyond. Experimental Hematology 33 9-19.

Reibiger I \& Spanel-Borowski K 2000 Difference in localization of eosinophils and mast cells in the bovine ovary. Journal of Reproduction and Fertility 118 243-249.

Reynaud K, Cortvrindt R, Smitz J, Bernex F, Panthier JJ \& Driancourt MA 2001 Alterations in ovarian function of mice with reduced amounts of KIT receptor. Reproduction 12 229-237.

Ricken AM, Spanel-Borowski K, Saxer M \& Huber PR 1995 Cytokeratin expression in bovine corpora lutea. Histochemistry and Cellular Biology 103 345-354.

Rodgers RJ, Waterman MR \& Simpson ER 1986 Cytochromes P-450scc, P-450(17)alpha, adrenodoxin, and reduced nicotinamide adenine dinucleotide phosphate-cytochrome P-450 reductase in bovine follicles and corpora lutea. Changes in specific contents during the ovarian cycle. Endocrinology 118 1366-1374.

Rönnstrand I 2004 Signal transduction via the stem cell factor receptor/KIT. Cellular and Molecular Life Sciences 61 2535-2548.

Ruiz de Almodovar C, Luttun A \& Carmeliet P 2006 An SDF-1 trap for myeloid cells stimulates angiogenesis. Cell 124 18-21.

Sakumoto R, Murakami S, Kishi H, Iga K, Okano A \& Okuda K 2000 Tumor necrosis factor-alpha and its receptor in the corpus luteum of pregnant cows. Molecular Reproduction and Development 55 406-411.

Schams D \& Berisha B 2004 Regulation of corpus luteum function in cattle an overview. Reproduction in Domestic Animals 39 241-251.

Smith MF, McIntush EW \& Smith GW 1994 Mechanisms associated with corpus luteum development. Journal of Animal Science 72 1857-1872.

Spanel-Borowski K \& Ricken AM 1997 Evidence for the maintenance of macrophage-like cells in long-term bovine granulosa cell cultures. Cell and Tissue Research 288 529-538.

Spanel-Borowski K, Rahner P \& Ricken AM 1997 Immunolocalization of CD18-positive cells in the bovine ovary. Journal of Reproduction and Fertility 111 197-205.

Sugino N, Suzuki T, Sakata A, Miwa I, Asada H, Taketani T, Yamagata Y \& Tamura H 2005 Angiogenesis in the human corpus luteum: changes in expression of angiopoietins in the corpus luteum throughout the menstrual cycle and in early pregnancy. Journal of Clinical Endocrinology and Metabolism 90 6141-6148.

Taylor ML \& Metcalfe DD 2000 Kit signal transduction. Hematology/ Oncology Clinics of North America 14 517-535.

Vakiani E, Cattoretti G, Colovai AI, Murty VV, Alobeid B \& Bhagat G 2005 CD117 expression in diffuse large B-cell lymphomas: fact or fiction? Pathology International 55 716-723.

Wang CH, Anderson N, Li SH, Szmitko PE, Cherng WJ, Fedak PW, Fazel S, Li RK, Yau TM, Weisel RD, Stanford WL \& Verma S 2006 Stem cell factor deficiency is vasculoprotective: unraveling a new therapeutic potential of imatinib mesylate. Circulation Research 99 617-625.

Yoshida H, Takakura N, Kataoka H, Kunisada T, Okamura H \& Nishikawa SI 1997 Stepwise requirement of KIT tyrosine kinase in mouse ovarian follicle development. Developmental Biology 184 122-137.

Received 23 May 2007

First decision 25 June 2007

Accepted 7 August 2007 